\title{
NITROGEN BALANCE OF BARROWS (15-30 KG) FED LOW PROTEIN AND DIFFERENT DIGESTIBLE ISOLEUCINE LEVELS
}

\begin{abstract}
BALANÇO DE NITROGÊNIO EM SUÍNOS, MACHOS CASTRADOS (15-30 KG), ALIMENTADOS COM BAIXA PROTEÍNA E DIFERENTES NÍVEIS DE ISOLEUCINA DIGESTÍVEL
\end{abstract}

\author{
Castilha, L.D. ${ }^{1 *}$; Pozza, P.C. ${ }^{1}$; Nunes, R.V. ${ }^{2}$; Lazzeri, D.B. ${ }^{2}$; Neumann, M.E. ${ }^{2}$ \\ and Richart, E. ${ }^{2}$
}

\begin{abstract}
'Programa de Pós-Graduação em Zootecnia. Universidade Estadual de Maringá (UEM/PR). Maringá. Paraná. Brasil. *leandrocastilha@hotmail.com

2Programa de Pós-Graduação em Zootecnia. Universidade Estadual do Oeste do Paraná. Marechal Cândido Rondon. Paraná. Brasil.
\end{abstract}

\section{AdDITIONAL KEYWORDS}

Isoleucine. Nitrogen. Swines.

\section{SUMMARY}

Twenty crossbred castrated barrows, averaging $22.26 \pm 1.79 \mathrm{~kg}$ of body weight, were used. The animals were individually alloted in metabolic cages, in a randomized blocks design, with five treatments $(0.45,0.52,0.59,0.66$ and $0.73 \%$ of digestible isoleucine) and four replicates. The diets were based on corn and soybean meal with low crude protein $(14.15 \%)$ and different levels of digestible isoleucine. The diets were humidified and supplied twice a day $(7 \mathrm{am}$ and 7 $\mathrm{pm}$ ) to reduce losses and facilitate ingestion. The experimental period lasted 12 days, being 7 days for adaptation to metabolic cages and experimental diets and 5 days for total feces and urine collection. Feces were analyzed for dry matter and nitrogen $(\mathrm{N})$, whereas urine samples were analyzed for $\mathrm{N}$. The plasma urea nitrogen was also determined. Then, the $\mathrm{N}$ intake, $\mathrm{N}$ excretion (feces and urine), $\mathrm{N}$ absorbed, $\mathrm{N}$ retention, $\mathrm{N}$ retention/ $\mathrm{N}$ intake, $\mathrm{N}$ retention/ $\mathrm{N}$ absorbed and total $\mathrm{N}$ excretion were determined. Only N intake (g/kg BW ${ }^{0.75} /$ day) was influenced $(p<0.05)$ by digestible isoleucine levels, showing a linear increase on $\mathrm{N}$ intake as digestible isoleucine levels increased in the diets.

\section{RESUMO}

Foram utilizados vinte suínos mestiços, machos castrados, com peso vivo inicial médio de $22,26 \pm 1,79 \mathrm{~kg}$; distribuídos individualmente em

\author{
PalaVRas chaVe adicionais \\ Isoleucina. Nitrogênio. Suínos.
}

gaiolas de metabolismo, em um delineamento experimental de blocos ao acaso, com cinco tratamentos $(0,45 ; 0,52 ; 0,59 ; 0,66 ; 0,73 \%$ de isoleucina digestível) e quatro repetições. As dietas foram formuladas à base de milho e farelo de soja, com baixa proteína bruta $(14,15 \%)$, e diferentes níveis de isoleucina digestível. As dietas foram umedecidas e fornecidas duas vezes ao dia ( 7 e $19 \mathrm{~h}$ ) para reduzir perdas e facilitar a ingestão. O período experimental teve duração de 12 dias, sendo 7 dias para adaptação às gaiolas metabólicas e rações experimentais e 5 dias de coleta total de fezes e urina. Posteriormente, foi determinado o teor de matéria seca das fezes e o teor de nitrogênio $(\mathrm{N})$ das fezes e urina, bem como o nitrogênio da uréia plasmática. Foram, então, calculados o consumo de $\mathrm{N}$, excreção de $\mathrm{N}$ (fezes e urina), $\mathrm{N}$ absorvido, $\mathrm{N}$ retido, $\mathrm{N}$ absorvido/ $\mathrm{N}$ retido, $\mathrm{N}$ retido/ $\mathrm{N}$ consumido, $\mathrm{N}$ retido/ $\mathrm{N}$ absorvido e excreção total de N. Obteve-se significância $(p<0,05)$ apenas para o nitrogênio ingerido $(g / k g$ $\mathrm{PV}^{0,75} / \mathrm{dia}$ ), em que o modelo linear apresentou aumento nos valores de $\mathrm{N}$ ingerido à medida que aumentaram os níveis de isoleucina digestível nas rações.

\section{INTRODUCTION}

The level of dietary protein in growing and finishing phases can be reduced in $4 \%$ 


\section{CASTILHA, POZZA, NUNES, LAZZERI, NEUMANN AND RICHART}

without affecting the growth rate and feed efficiency when adequate amounts of essential amino acids are provided in diet (Jongbloed and Lenis, 1998). Among the essential amino acids, lysine, threonine, methionine and tryptophan are key amino acids. However, Liu et al. (1999) suggested that isoleucine must be a limiting amino acid in corn and soybean meal diets with low protein for growing-finishing pigs. Parr et al. (2003) reported that pigs fed a deficient isoleucine diet had a depression in performance compared to animals fed a positive control diet, and also showed a reestablishment of performance as the isoleucine was supplemented in the diet.

With the availability of the synthetic amino acids lysine, tryptophan, threonine and methionine, the crude protein levels may be reduced in diets for pigs so as to reduce nitrogen excretion and negative impact of manure on the environment (Jongbloed and Lenis, 1998). However, to reduce crude protein in the diet, adequate knowledge of the isoleucine requirements is necessary (Kerr et al., 2004).

Thus, the purpose of this study was to evaluate the nitrogen balance and plasma urea nitrogen of barrows fed diets with reduced crude protein and different levels of digestible isoleucine.

\section{MATERIALS AND METHODS}

A nitrogen balance trial was carried out to evaluate diets with different levels of digestible isoleucine (Dig Ile) for swine. The assay was carried out in the experimental farm of State University of West Parana, Brazil. The Animal Welfare Committee of the university approved all animal care procedures.

Twenty crossbred barrows (Pietráin $\mathrm{x}$ Landrace $x$ Large White) with an average body weight of $22.26 \pm 1.79 \mathrm{~kg}$ were used in this study. The animals were individually housed, distributed in a randomized blocks design with five treatments and four repli- cates. Treatments consisted of five lowprotein diets $(14.50 \%)$ with increasing Dig Ile levels. A basal diet (0.45\% Dig Ile) was formulated and crystalline amino acids (Llysine, L-threonine, DL-methionine, Ltryptophan and L-valine) were added to keep the nutritional recommendations for castrated males ranging from 15 to $30 \mathrm{~kg}$ (Rostagno et al., 2005) and L-isoleucine was used, replacing the inert material in the experimental diets, to assure the levels of $0.52,0.59,0.66$ and $0.73 \%$ Dig Ile. Glutamic acid was used to provide the same nitrogen level in all diets.

The metabolism assay used a seven day adjustment period, followed by a five day period of total collection of feces and urine. Pigs were housed in stainless-steel metabolism cages, equipped with feeders and compartments which allowed separating feces and urine. Barrows were fed twice a day (07 am and $07 \mathrm{pm})$ and the ration remained at the feeder until total intake. After each meal water was freely offered. Ferric oxide $\left(\mathrm{Fe}_{2} \mathrm{O}_{3}\right)$ was used to indicate the beginning and the end of fecal collection period. Feces were collected twice a day, placed into plastic bags and stored $\left(-18^{\circ} \mathrm{C}\right)$. Urine was collected continuously over the 5 day collection period through a funnel into a plastic bucket with $20 \mathrm{~mL}$ of $1: 1$ chloridic acid $(\mathrm{HCl})$ as preservative. Urine volume was measured and recorded daily and a $5 \%$ aliquot was retained and stored $\left(-5^{\circ} \mathrm{C}\right)$. Prior to analyses, feces were thawed and mixed thoroughly. Feces samples were dried at $55^{\circ} \mathrm{C}$, ground through a $1 \mathrm{~mm}$ screen and then stored in plastic bags. Urine samples were thawed and strained through a filter prior to nitrogen analysis.

The $\mathrm{N}$ content of diets, feces and urine samples was analyzed by Kjeldahl procedure (AOAC, 1999). Then, the $\mathrm{N}$ intake, $\mathrm{N}$ excretion (feces and urine), $\mathrm{N}$ absorbed, $\mathrm{N}$ retention, $\mathrm{N}$ retention/ $\mathrm{N}$ intake, $\mathrm{N}$ retention/ $\mathrm{N}$ absorbed and total $\mathrm{N}$ excretion were determined. At the end of the collection period all pigs were bled once via jugular 
vein puncture using heparinized tubes for analysis of plasma urea nitrogen (PUN). Samples were gently shaken and stored on ice. Plasma was obtained by centrifugation at $3000 \mathrm{x} g$ for 10 minutes at $20^{\circ} \mathrm{C}$, and stored at $-10{ }^{\circ} \mathrm{C}$ until analysis of PUN by colorimetric method.

Nitrogen balance and PUN data were submitted to the analysis of variance (ANOVA) using the general linear models (GLM) procedure of SAS (SAS, 1999). A polinomial regression was used to estimate the best level of digestible isoleucine. Linear and quadratic models were used to show effects of increasing levels of digestible isoleucine on nitrogen balance, according to the adjustment obtained for each parameter. Significance was declared at $\mathrm{p}<0.05$ for all parameters evaluated.

\section{RESULTSANDDISCUSSION}

The increase in Dig Ile levels did not affect ( $p>0.05) \mathrm{N}$ excretion (feces or urine), $\mathrm{N}$ absorption, $\mathrm{N}$ retention, $\mathrm{N}$ retention: $\mathrm{N}$ intake ratio, $\mathrm{N}$ retention: $\mathrm{N}$ absorption ratio, total $\mathrm{N}$ excretion and PUN of the barrows, as shown in table I. Probably, as the diets had provided the amino acid requirements for the fith first amino acids for pigs, only varying the levels of isoleucine (sixth essential amino acid) at levels that were not enough to cause any unbalance or protein catabolism, the nitrogen metabolism was not affected.

According to Moser et al. (2000) the interrelationship among branched chain amino acids (BCAA) may alter its metabolism in the animal organism, since the excess of leucine can cause imbalance, raising the requirements of isoleucine and valine. This may cause metabolic effects on nitrogen excretion by increasing the amino acids catabolism.Although this assay has evaluated levels of Dig Ile, D'Mello (2003) affirm that a variation in leucine levels is more likely to alter nitrogen metabolism than other BCAA levels, since leucine is more powerful to induce antagonisms.

Parr et al. (2003) assessed levels of Dig Ile $(0.42$ to $0.58 \%$ ) for pigs ( 25 to $45 \mathrm{~kg}$ ) and observed that PUN decreased as levels of Dig Ile grew up, but at $0.50 \%$ there was a plateau. According to the authors, PUN values should decrease as a limiting AA reaches the requirement, and PUN should plateau after the requirement has been met. In the present assay it did not occur maybe

Table I. Nitrogen balance of barrows, from 15 to $30 \mathrm{~kg}$, fed diets with different levels of digestible isoleucine. (Balanço de nitrogênio em suínos, machos castrados, dos 15 aos $30 \mathrm{~kg}$, alimentados com dietas contendo diferentes níveis de isoleucina digestível).

\begin{tabular}{|c|c|c|c|c|c|c|c|}
\hline \multirow[t]{2}{*}{ Traits } & \multicolumn{5}{|c|}{ Levels of digestible isoleucine (\%) } & \multirow[b]{2}{*}{ SEM } & \multirow[b]{2}{*}{$\mathrm{p}$} \\
\hline & 0.45 & 0.52 & 0.59 & 0.66 & 0.73 & & \\
\hline 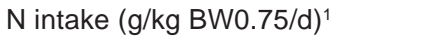 & 2.15 & 2.16 & 2.16 & 2.17 & 2.17 & 0.09 & $<0.05$ \\
\hline $\mathrm{N}$ feces (g/kg BW0.75/d) & 0.43 & 0.45 & 0.43 & 0.45 & 0.43 & 0.06 & NS \\
\hline N urine $(\mathrm{g} / \mathrm{kg}$ BW0.75/d) & 0.41 & 0.56 & 0.60 & 0.54 & 0.46 & 0.16 & NS \\
\hline $\mathrm{N}$ absorbed (g/kg BW0.75/d) & 1.72 & 1.71 & 1.73 & 1.72 & 1.74 & 0.12 & NS \\
\hline $\mathrm{N}$ retention $(\mathrm{g} / \mathrm{kg} B W 0.75 / \mathrm{d})$ & 1.30 & 1.15 & 1.13 & 1.18 & 1.29 & 0.15 & NS \\
\hline $\mathrm{N}$ retention/intake (\%) & 60.79 & 53.23 & 51.91 & 54.22 & 59.76 & 6.49 & NS \\
\hline $\mathrm{N}$ retention/absorbed (\%) & 75.91 & 67.20 & 64.79 & 68.25 & 73.91 & 8.26 & NS \\
\hline Total N excretion (g/kg BW0.75/d) & 0.84 & 1.01 & 1.03 & 0.98 & 0.89 & 0.15 & NS \\
\hline Plasma urea nitrogen (mg/dL) & 13.19 & 22.73 & 22.14 & 16.18 & 20.89 & 7.11 & NS \\
\hline
\end{tabular}

${ }^{1}$ Linear effect $(Y=2.1102+0.08526 X) ; N S=p>0.05$. 


\section{CASTILHA, POZZA, NUNES, LAZZERI, NEUMANN AND RICHART}

because the assessed levels of Dig Ile were not sufficiently above or below the requirements of the pigs. Therefore, there was not an AA unbalance, neither a PUN plateau.

However, increasing Dig Ile levels led to increasing ( $\mathrm{p}<0.05) \mathrm{N}$ intake ( $\mathrm{g} / \mathrm{kg}$ BW0.75/ d). Higher N intake was likewise reported by Wiltafsky et al. (2009) that evaluated Dig Ile levels ( 0.36 to $0.72 \%$ ) for barrows ( 10 to 20 $\mathrm{kg}$ ) and observed a linear increase in $\mathrm{N}$ intake according to the higher Dig Ile levels in diets. The authors identified effect on $\mathrm{N}$ retention, with values ranging between 5.51 and $9.12 \mathrm{~g} / \mathrm{d}$, which was not observed in this study. The $\mathrm{N}$ retention: $\mathrm{N}$ intake ratio obtained in this study varied between 51.91 and $60.79 \%$.

\section{REFERENCES}

AOAC. 1999. Official Methods of Analysis. $16^{\text {th }} \mathrm{ed}$. Association of Official Analytical Chemists. Washington.

Barea, R.; Brossard, L.; Le Floc'h, N.; Primot, Y. and Van Milgen, J. 2009. The standardized ileal digestible isoleucine-to-lysine requirement ratio may be less than fifty percent in eleven- to twenty-three-kilogram piglets. J Anim Sci, 87: 4022-4031.

D'Mello, J.P.F. 2003. Amino acids in animal nutrition. $2^{\text {nd }}$ ed. CABI Publishing. Edinburgh. 515 pp.

Jongbloed, A.W. and Lenis, N.P. 1998. Environmental concerns about animal manure. J Anim Sci, 76: 2641-2648.

Kerr, B.J.; Kidd, M.T.; Cuarón, J.A.; Bryant, K.L.; Parr, T.M.; Maxwell, C.V. and Campbell, J.M. 2004. Isoleucine requirements and ratios in starting (7 to $11 \mathrm{~kg}$ ) pigs. J Anim Sci, 82: 23332342.

Liu, H.; Allee, G.L.; Berkemeyer, J.J.; Touchette, K.J.; Spencer, J.D. and Kim, I.B. 1999. Effect of reducing protein level and adding amino acids on growth performance and carcass characteristics of finishing pigs. J Anim Sci, 77 (Suppl.
In summary Barea et al. (2009) observed that $0.50 \%$ of digestible isoleucine for swines ( 11 to $23 \mathrm{~kg}$ ) was enough to meet its requirements, based on growth performance and blood parameters. With values close to those obtained in this study, Wiltafsky et al. (2009) proposed $0.56 \%$ (10 to $20 \mathrm{~kg}$ ), based on $\mathrm{N}$ balance.

\section{CONCLUSIONS}

Nitrogen balance and plasma urea nitrogen of barrows (15-30 kg) varied among increasing levels of digestible isoleucine. In further researches, when crude protein is reduced, levels lower than 0.45 of digestible isoleucine and higher than $0.73 \%$ must be evaluated.

1): 69 (Abstr.).

Moser, S.A.; Tokach, M.D.; Dritz, S.S.; Goodband, R.D.; Nelssen, J.L. and Loughmiller, J.A. 2000. The effects of branched-chain amino acids on sow and litter performance. J Anim Sci, 78: 658-667.

Parr, T.M.; Kerr, B.J. and Baker, D.H. 2003. Isoleucine requirement of growing (25 to $45 \mathrm{~kg}$ ) pigs. $J$ Anim Sci, 81: 745-752.

Rostagno, H.S.; Albino, L.F.T.; Donzele, J.L.; Gomes, P.C.; Oliveira, R.F.M.; Lopes, D.C.; Ferreira, A.S. e Barreto, S.L.T. 2005. Tabelas brasileiras para aves e suínos. Composição de alimentos e exigências nutricionais. UFV. Viçosa.

SAS. 1999. SAS Institute. SAS/STAT user's guide. Version 6.12. Cary, NC.

Wiltafsky, M.K.; Bartelt, J.; Relandeau, C. and Roth, F.X. 2009. Estimation of optimum ratio of standardized ileal digestible isoleucine to lysine for eight- to twenty-five-kilogram pigs in diets containing spray-dried blood cells or corn gluten feed as protein source. J Anim Sci, 87: 25542564. 